\title{
DESCRIPTIVE ANALYSIS OF DECISION-MAKING CRITERIA FOR BUILDING RETROFIT CONSTRUCTION: A CASE STUDY OF BANGLADESH
}

\author{
Rumiko Sasaki $^{1^{*}}$, Tsuyoshi Seike ${ }^{2}$, Yongsun $\mathrm{Kim}^{3}$ \\ ${ }^{1}$ Assistant Professor, Faculty of Urban Environment Studies, Tokyo Metropolitan University, 7th Floor, Building No. 9 , \\ Minami Oosawa, Hachioji, Tokyo, Japan \\ ${ }^{2}$ Associate Professor, Graduate School of Frontier Science, University of Tokyo, 6th Floor, Environmental building, \\ Kashiwanoha 5-1-5, Kashiwa, Chiba, Japan \\ ${ }^{3}$ Researcher, Graduate School of Frontier Science, University of Tokyo, 6th Floor, Environmental building, Kashiwanoha 5- \\ 1-5, Kashiwa, Chiba, Japan \\ *Corresponding author; Email: rsasaki@tmu.ac.jp, rumiko518s@ gmail.com ${ }^{1}$
}

\begin{abstract}
This paper is an exploratory study adopting a descriptive approach to clarify the background of technology adoption, role of multiple stakeholders, and decision-making processes in Bangladesh from the perspective of the possible technology dissemination. In addition, this study identifies the factors influencing decision-making on the basis of semi-structured interview in terms of frontend projects. In the retrofit process, assessments, standards, design policies, construction methods, and materials are mainly determined at the planning stage. International standards are a promoting factor in obtaining owner approval in technology selection, whereas cost and material procurement are the suppressing factors. The stakeholders in providing and diffusing new technology are technical consultants and structural designers, who are involved in the initial phase of the process. For technology diffusion within Bangladesh, these stakeholders must be acknowledged and worker education must be considered.
\end{abstract}

Keywords: Technical Stakeholders; seismic retrofit; decision making process; technology adoption; descriptive analysis.

\section{INTRODUCTION}

The construction process extends from building work to civil engineering projects. Several factors such as regulation, worker skills/knowledge, and material procurement enhance the building construction quality. However, building construction realities in developing countries are yet to be identified. Even if appropriate technology is provided by international aid organizations, its practical dissemination on the local construction site is considerably problematic because technical stakeholders select the construction method based on the tacit complicated criteria. The selected methods are either studied only for civil engineering projects or are studied for both civil engineering and building engineering projects. In particular, building renovation projects make decisionmaking more complicated through overall construction flow. Despite the presence of uncertain complicated factors involved in decision-making, the decision-making process for building construction projects in developing countries has not yet been sufficiently researched (Okazaki, 2009; Furusaka, 1989; Furusaka, 1988; Kitajima, 2006; Kitajima, 2004; Kitajima, 2003; Kitajima, 2001; Tazaka, 2013).

With regard to construction projects, research on decision-making mainly follows a normative approach to develop a decision support system (DSS). Multi-attribute decision-making aims to select an appropriate choice from the alternatives (Chankong \& Haimes, 1983). It is concerned with the contract or bidding system (Lesniak, 2013; Loh, 2015; Ling, 2009), predicts construction duration (Nguyen, 2013; Tam, 2002), and selects appropriate construction methods (Ximena, 2014; Yun, 2017), based on a multicriteria decision-making process (Hurtado \& Bruno 2005). The developed method multi-attribute value technique (MAVT) has extended its use on architect selection (Ling, 2003), engineering consultant's selection (Ng \& Chow, 2004). The criteria such as cost, time, and quality are listed (Ximena, 2014), and the construction method characteristics are disclosed as one of criteria (Youssef, Anumba, \& Thorpe, 2005; Soetanto, Glass, Dainty, \& Price, 2007). Previous research (Castro-Lacouture, Sefair, Florez, \& Medaglia, 2009) considered the impact of economic, social, environmental, and constructability factors to select structural materials. Yun (2017) clarified that the priority of economic sustainability for the structural frame material selection higher than that of environmental sustainability and constructability performance.

The realities of decision-making with regard to construction projects partially rely on implied know- 
ledge. Knowledge is the information with a context that provides the basis for actions and decisionmaking (Kanter, 1999). Ahmed (2006) highlighted the barriers of a construction organization, such as the status of knowledge, location of knowledge, and culture surrounding the knowledge. Knowledge exists in a tacit or explicit status (Nonaka \& Takeuchi, 1995). Tacit knowledge is stored in peoples' brains as mental models, experiences, and skills and cannot be easily communicated externally (Vail, 1999). In contrast, explicit knowledge is encoded in formal models, rules, documents, drawings, products, services, facilities, systems, and processes (Vail, 1999). Although construction decision-making based on explicit knowledge is systematized in decision-making analysis, decision-making based on tacit knowledge is hardly studied, leaving unavoidable determination factors for the construction projects. Knowledge, attitude, and practice (KAP) of multiple stakeholders (Yi, 2017), including architects, civil and structural engineers, mechanical and electrical engineers, developers/ clients, and project managers are required to comprehensively grasp the construction realities of lowincome countries.

Simon (1945) and March and Simon (1958) developed the descriptive theory that aims to clarify non-programmed decision-making by focusing on the intelligence, design, and choice activities by organization, and developed by several researchers such as the science of mudding through (Lindblom, 1959), the structure of unstructured decision process (Mintzberg, Raisinghani, \& Theoret, 1976), and garbage can model (Cohen, March, \& Olsen, 1972). Furthermore, the effectiveness of the frontend planning (FEP) affects project cost and schedule performance (Gibson \& Hamilton, 1994). FEP is relatively new in Asian countries, less than half, $44 \%$ projects adopted even in well-developed Singapore (Bon-Gang, 2012).

This research is an exploratory study adopting a descriptive approach to clarify the non-programmed decision-making process, concrete frontend project flow, technology selection, and role of multiple stakeholders in order to identify the factors affecting material determinations in low-income countries.

\section{CASE STUDY}

Among the developing countries, this paper selected Bangladesh (located in South Asia). United Nations has identified Bangladesh as a country prone to seismic risks. Although no significant damage has been observed following recent earthquakes, rapid urbanization has led to the development of several structurally vulnerable reinforced concrete (RCC) buildings. The reason why Bangladesh is selected as a case is that international technical cooperation projects have been undertaken by the national government to enhance the building strength. In order to grasp the potential of technology's future diffusion, the international project regarding the building strength is considered for case selection.

\section{METHODOLOGY}

The semi-structured interview addressed the factors affecting technology adoption and the decision-making process in building assessment, design, and construction. A field survey of five ongoing renovation projects (Table 1) and semistructured interviews with the 18 relevant construction officials was conducted thrice, i.e., in November 2013, February 2014, and August 2014. Experts from a research institute and two private general contracting companies involved in technical consultancy, structural design, and construction management were interviewed. The types of renovation work included repairing rusting rebar and the damage caused by fire, modifying the existing building layout, and reinforcing the structure. The analysis involved a summary of the overall project flow, verification of the role of the technical stakeholders, and decisionmaking factors.

\section{RESULTS; DECISION-MAKING FOR THE RETROFITING PROJECT FLOW}

\section{Ordering Phase}

Table 2 summarizes the rationale for taking recourse to a renovation project. Each request was made by the building's owner or user. Case 1 involved repairs to a portion of the building damaged by fire, and Cases 2 and 3 involved renovations such as altering the building layout. By contrast, in Cases 4 and 5 , a request was made because the owner was concerned regarding the structural strength of their building in view of vertical extensions having been constructed without structural reinforcement. The table shows several recent cases involving the owners' concerns regarding buildings' structural performance as well as cases brought on by necessity. The strict enforcement of legal regulations was one of the factors identified in the interview pertaining to Case 4. It is understood that the impact of building collapse accidents has affected owners' interest toward improving buildings' structural performance. Tabel 2. 
Table 1. Case Outline and Interviewee

\begin{tabular}{|c|c|c|c|c|c|}
\hline Case & Case 1 & Case 2 & Case 3 & Case 4 & Case 5 \\
\hline Construction & $\begin{array}{l}\text { Repair the damaged } \\
\text { part caused by fire }\end{array}$ & $\begin{array}{l}\text { Structure strengthened } \\
\text { by renovation }\end{array}$ & $\begin{array}{l}\text { Repair with usage } \\
\text { alteration and } \\
\text { aging }\end{array}$ & $\begin{array}{l}\text { Strengthen the } \\
\text { structure }\end{array}$ & $\begin{array}{l}\text { Strengthen the } \\
\text { structure }\end{array}$ \\
\hline Usage & Garment factory & Mosque & $\begin{array}{l}\text { Factory } \\
\text { commercial } \\
\text { building }\end{array}$ & \multicolumn{2}{|c|}{$\begin{array}{c}\text { Commercial buildingCommercial } \\
\text { building }\end{array}$} \\
\hline Structure & $\begin{array}{l}\text { RCC frame with brick } \\
\text { masonry wall }\end{array}$ & $\begin{array}{l}\text { RCC frame with brick } \\
\text { masonry wall }\end{array}$ & $\begin{array}{l}\text { RCC frame with } \\
\text { brick masonry } \\
\text { wall }\end{array}$ & $\begin{array}{l}\mathrm{RCC} \text { frame with } \\
\text { brick masonry wall }\end{array}$ & $\begin{array}{l}\text { RCC frame with } \\
\text { RCC wall }\end{array}$ \\
\hline No. of floors & 5 & 2 & 6 & 7 & 12 \\
\hline Location & Dhaka suburb & Dhaka & Dhaka & Dhaka & Dhaka \\
\hline Renovation period & $\begin{array}{l}\text { Act. } 2013 \text { to Nov. } \\
2013\end{array}$ & $\begin{array}{l}\text { Feb. } 2013 \text { to Jun. } 2014 \\
\text { (plan) }\end{array}$ & N/A & $\begin{array}{l}\text { Jan. } 2014 \text { to } \\
\text { discontinuation }\end{array}$ & $\begin{array}{l}\text { Jan. } 2014 \text { to non- } \\
\text { scheduled }\end{array}$ \\
\hline $\begin{array}{l}\text { Intervi Technical } \\
\text { ewee consultant }\end{array}$ & $\begin{array}{l}\text { Research institute B } \\
\text { (Mr. A) }\end{array}$ & $\begin{array}{l}\text { Contractor S } \\
\text { (Mr. T) }\end{array}$ & $\begin{array}{l}\text { Contractor S } \\
\text { (Mr. T) }\end{array}$ & $\begin{array}{l}\text { Contractor E } \\
\text { (Mr. M) }\end{array}$ & $\begin{array}{l}\text { Research institute } \\
\text { B (Mr. I) }\end{array}$ \\
\hline $\begin{array}{l}\text { Structural } \\
\text { engineer }\end{array}$ & $\begin{array}{l}\text { Contractor E } \\
\text { (Mr. M) }\end{array}$ & $\begin{array}{l}\text { Contractor S } \\
\text { (Mr. T) }\end{array}$ & $\begin{array}{l}\text { Contractor S } \\
\text { (Mr. T) }\end{array}$ & $\begin{array}{l}\text { Research institute B } \\
\text { (Mr. R) }\end{array}$ & $\begin{array}{l}\text { Contractor K } \\
\text { (N/A) }\end{array}$ \\
\hline $\begin{array}{l}\text { Constructio } \\
\mathrm{n} \text { manager }\end{array}$ & $\begin{array}{l}\text { Contractor E } \\
\text { (Mr. B) }\end{array}$ & $\begin{array}{l}\text { Contractor L } \\
\text { (Mr. D, Mr. E, Mr. F) }\end{array}$ & $\begin{array}{l}\text { Contractor J } \\
(\mathrm{Mr} . \mathrm{H})\end{array}$ & $\begin{array}{l}\text { Contractor E } \\
(\mathrm{Mr} . \mathrm{J})\end{array}$ & $\begin{array}{l}\text { Contractor E } \\
(\mathrm{Mr} . \mathrm{L}, \mathrm{Mr} . \mathrm{N})\end{array}$ \\
\hline $\begin{array}{l}\text { Field } \\
\text { worker }\end{array}$ & $\begin{array}{l}\text { Contractor E } \\
\text { (Mr. C) }\end{array}$ & $\begin{array}{l}\text { Contractor L } \\
(\mathrm{Mr} . \mathrm{G})\end{array}$ & $\begin{array}{l}\text { Contractor J } \\
\text { (Mr. I) }\end{array}$ & $\begin{array}{l}\text { Contractor E } \\
(\mathrm{Mr} . \mathrm{K})\end{array}$ & $\begin{array}{l}\text { Contractor E } \\
\text { (Mr. O, Mr. P) }\end{array}$ \\
\hline $\begin{array}{l}\text { Total number of } \\
\text { interviewee }\end{array}$ & 4 & 5 & 3 & 4 & 5 \\
\hline
\end{tabular}

Table 2. Deciding Factors for Ordering Renovation Construction

\begin{tabular}{|c|c|c|c|}
\hline Case & Ordered by & Background & Factor \\
\hline 1 & Garment factory owner & To repair fire damage, although newly constructed & Fire damage \\
\hline 2 & User & To renovate & Building plan alternation \\
\hline 3 & $\begin{array}{l}\text { Commercial building } \\
\text { owner }\end{array}$ & To renovate with usage change & $\begin{array}{l}\text { Building usage } \\
\text { alternation }\end{array}$ \\
\hline 4 & $\begin{array}{l}\text { Commercial building } \\
\text { owner }\end{array}$ & $\begin{array}{l}\text { Owner was concerned about building structural performance } \\
\text { because it was vertically extended without reinforcement } \\
\text { forced by government legislation }\end{array}$ & $\begin{array}{l}\text { Consciousness } \\
\text { enhancement/change of } \\
\text { circumstances }\end{array}$ \\
\hline 5 & $\begin{array}{l}\text { Commercial building } \\
\text { owner }\end{array}$ & $\begin{array}{l}\text { Owner was concerned about building structural performance } \\
\text { because it was vertically extended without reinforcement } \\
\text { Since shop owners disagree to retrofit, determined by the court }\end{array}$ & $\begin{array}{l}\text { Consciousness } \\
\text { enhancement }\end{array}$ \\
\hline
\end{tabular}

\section{Structural Assessment}

Structural assessment of an existing building is generally required before a structural retrofit. This part summarizes the renovation project through descriptions of assessment methods, interviews with conductors and knowledge providers, and accounts of decision-making processes.

Table 3 summarizes the diagnostic methods, conductors, knowledge providers, and additional data on the basis of construction documentation, which was collected through interviews with technical consultants and structural designers. In Case 1, the design documentation did not exist; therefore, the actual design layout was prepared anew. In Case 4, a professional diagnostic firm and the general contractor conducted the building diagnosis.
Building investigations are based on a visual inspection of the presence or absence of cracking or deteriorating concrete. Surveys of cracks in hidden parts or in a building damaged by fire and crack depth investigation using a non-destructive concrete tester (ultrasonic pulse velocity (UPV) meter) were conducted.

Projects by General Contractor E (i.e., Cases 1, 4, and 5) adopted a detailed concrete compressive strength test with the core test and the Schmidt hammer. In this case, the compressive strength by core testing is adjudged insufficient; therefore, a detailed investigation of the thickness of concrete was conducted using an ultrasonic non-destructive concrete tester. Furthermore, a rebar arrangement and covering depth investigation were conducted using a Ferroscan device (Hilti Corp.). 
Table 3. Assessment Method

\begin{tabular}{|c|c|c|c|c|c|c|}
\hline \multirow{2}{*}{\multicolumn{2}{|c|}{$\frac{\text { Case }}{\text { Conductor }}$}} & Case 1 & Case 2 & Case 3 & Case 4 & Case 5 \\
\hline & & $\begin{array}{l}\text { Technical } \\
\text { consultant }\end{array}$ & $\begin{array}{l}\text { Technical consultant, } \\
\text { structural designer }\end{array}$ & $\begin{array}{l}\text { Technical consultant, } \\
\text { structural designer }\end{array}$ & $\begin{array}{l}\text { Testing firm, } \\
\text { Structural designer }\end{array}$ & $\begin{array}{l}\text { Technical } \\
\text { consultant }\end{array}$ \\
\hline \multicolumn{2}{|c|}{ Knowledge provider } & $\begin{array}{l}\text { Technical } \\
\text { consultant }\end{array}$ & $\begin{array}{l}\text { Technical consultant, } \\
\text { structural designer }\end{array}$ & $\begin{array}{l}\text { Technical consultant, } \\
\text { structural designer }\end{array}$ & Structural designer & $\begin{array}{l}\text { Technical } \\
\text { consultant }\end{array}$ \\
\hline \multicolumn{2}{|c|}{ Design document } & Available & None & None & None & None \\
\hline $\begin{array}{l}\text { Visual } \\
\text { inspection }\end{array}$ & Crack detection & Done & Done & Done & Done & Done \\
\hline Core test & $\begin{array}{l}\text { Concrete } \\
\text { compression }\end{array}$ & Done & None & None & None & Done \\
\hline $\begin{array}{l}\text { Schmidt } \\
\text { hammer }\end{array}$ & $\begin{array}{l}\text { Concrete } \\
\text { compression }\end{array}$ & Done & None & None & Done & Done \\
\hline UPV & $\begin{array}{l}\text { Crack detection, } \\
\text { Concrete thickness }\end{array}$ & Done & None & None & Done & N/A \\
\hline Ferroscan & $\begin{array}{l}\text { Rebar arrangement, } \\
\text { covering depth }\end{array}$ & None & None & None & Done & Done \\
\hline
\end{tabular}

Conversely, for Cases 2 and 3 in which General Contractor $\mathrm{S}$ was involved, only visual inspections were performed; quality inspections of the existing layout and structural calculations were neglected. Indeed, the inspection equipment used for testing existing structures has not been adopted as yet in Bangladesh. It was also observed that the introduction of new technology such as concrete compressors from China was planned. However, actual testing was limited to cases where General Contractor E was involved, and there were significant differences in the building research methods. From an interview with a building structure academician at a Bangladeshi university, who said: "UPV is very costly and does not need to be introduced," it is clear that the initial cost of the equipment is an inhibiting factor for selecting methods. Since the knowledge provider is also a technical consultant, they play a role in determining the technical level at the building investigation stage.

The assessment method used in Bangladesh does not include a target value for the diagnosis. Instead of strengthening the building as a countermeasure against disaster, the purpose is to meet the requirements of building codes, aiming to reproduce a structural design layout. It is clear that a seismological diagnosis method has not yet been established in Bangladesh.

In Case 1, the construction firm decided to conduct a retrofit despite achieving a satisfactory structural performance. In Cases 2 and 3, the contractor takes the responsibility of decision-making.

\section{Structural Design}

\section{Building standards selection}

Planning and design were conducted on the basis of the structural performance of the existing building after building assessment. Interviews with the structural designer and the technical consultant were conducted from the perspective of meeting the criteria specified in reference material. The criteria to be adopted for structural design were mostly from the Bangladesh National Building Code (BNBC), and in some cases, standards of the American Concrete Institute (ACI) were also used as a reference. Load factors in BNBC were set against the seismic load (and wind load in the case of high-rise buildings) and are also conducted at the practice stage. The reason for referring to ACI is the achievement of international standards. Another reason is that BNBC is mainly a reference guide for new buildings, so for existing buildings, ACI standards are required.

Contractor E utilized new imported materials as it was already established as a subsidiary of an international company as a materials supplier. Further, the design policy of the international materials manufacturer was also recommended, particularly in concrete repair, reinforcing, and waterproofing. It conformed to the production management policy BS EN 1504. For the suspension of concrete, ACI 440 was used as the reference for the three cases. In particular, BS EN1504, Part 9, "Products and Systems Used in the Policy," describes 11 policies related to correcting the structural approach, defect investigation of concrete, and specifications for orders and designs. Health, safety, and structural and environmental resistance were factors influencing product selection.

\section{Construction method selection}

Table 4 summarizes collective information regarding reinforcing locations, main materials, and other proposed construction methods as well as the reasons behind the selections. The data were collected through interviews with structural designers and 
Table 4. Retrofit Method

\begin{tabular}{|c|c|c|c|c|c|}
\hline Case & Case 1 & Case 2 & Case 3 & Case 4 & Case 5 \\
\hline Method & Concrete jacketing & $\begin{array}{l}\text { Concrete jacketing } \\
\text { with additional iron } \\
\text { bar }\end{array}$ & $\begin{array}{l}\text { Concrete jacketing } \\
\text { with iron replacement }\end{array}$ & $\begin{array}{l}\text { Concrete jacketing } \\
\text { with additional iron } \\
\text { bar }\end{array}$ & $\begin{array}{l}\text { Concrete jacketing } \\
\text { with additional iron } \\
\text { bar }\end{array}$ \\
\hline Location & Beam, slab & Beam, slab & Column & Column & $\begin{array}{l}\text { Slab, column, exterior } \\
\text { wall }\end{array}$ \\
\hline $\begin{array}{l}\text { Proposed } \\
\text { method }\end{array}$ & $\begin{array}{l}\text { Iron plate/carbon fiber } \\
\text { sheet wrapping/glass } \\
\text { fiber sheet wrapping }\end{array}$ & None & None & Fiber sheet wrapping & None \\
\hline $\begin{array}{l}\text { Adoption } \\
\text { reason }\end{array}$ & $\begin{array}{l}\text { Owner request short } \\
\text { term construction }\end{array}$ & - & - & $\begin{array}{l}\text { Owners economic } \\
\text { situation }\end{array}$ & - \\
\hline $\begin{array}{l}\text { Knowledg } \\
\text { e source }\end{array}$ & $\begin{array}{l}\text { Consultant's } \\
\text { knowledge, } \\
\text { international } \\
\text { cooperation }\end{array}$ & $\begin{array}{l}\text { Consultant's } \\
\text { experience }\end{array}$ & $\begin{array}{l}\text { Consultant's } \\
\text { experience }\end{array}$ & $\begin{array}{l}\text { Consultant's } \\
\text { experience }\end{array}$ & $\begin{array}{l}\text { Consultant's } \\
\text { knowledge, } \\
\text { international } \\
\text { cooperation }\end{array}$ \\
\hline
\end{tabular}

technical consultants. All methods adopted "concrete jacketing using additional rebar and concrete." However, the cases involving Contractor E utilized micro-concrete, a new technology for Bangladesh, instead of common concrete. Micro-concrete is a "non-shrinking cementitious concrete" material, which has been regarded as a concrete repair material for RCC.

As for other proposed construction methods, various options using iron plate retrofits and fiberreinforced sheets were proposed. The reason for the disallowance of these methods was that the ordering stakeholder in Case 1 requested a short construction period. Since iron plate retrofits and fiber-reinforced sheet were unavailable in the country, prolonging the construction period was a concern because these materials would have had to be imported from abroad. For Case 4, fiber-reinforced sheets were refused by the ordering stakeholder because of the high cost. It can be seen that the price and time related to material procurement are factors influencing the adoption of new technology. In particular, the carbon fiber sheet has been attracting attention as a retrofit method because of its workability and quality assurance although the cost is very high. Limitations caused by the cost and time for importing materials have a negative impact on the diffusion of new technologies.

Contractor E used new technology to satisfy the owner. As the manufacturing company did international business and the product's performance had already been tested, it was easy to gain approval from the owner. Materials that meet international criteria are assumed to be an incentive for the adoption of technology.

The knowledge and experience possessed by consultants are the main source of the proposed technology. For example, in the case of Contractor E, the knowledge and experience of academicians became a source of technology. By contrast, Contractor $\mathrm{S}$ proposed the only domestic construction techniques; their representative mentioned, "We have gained much experience with this construction method." In both cases, technical consultants were clearly proponents of technologies, and those technologies were specified in the selections that they made.

\section{Construction}

\section{Process management}

Interviews with construction managers revealed the role of each technical stakeholder in terms of adoption and diffusion at the construction stage. In Case 1, a significant shortening of the construction period was identified. The originally planned 30-day construction period was shortened to 15 days once construction started.

Foreign buyers demanded that compliance with their terms be fulfilled in order for continued export of products from the garment factories. Doubling the size of the labor force was proposed as a solution. Laborers from small staffing companies were introduced. However, ensuring their skills in repair and renovation work was difficult. This shows that the construction schedule was changed to give priority to businesses in Bangladesh.

Cases 2 and 3, in which Contractor $\mathrm{S}$ was involved, did not have any particular trouble with the work plan. Case 2 did not present a clear timetable through the entire plan, and only a handwritten process table for about two weeks was available at the time of inspection. Moreover, the interviewee did not have a clear understanding of the construction completion time. This means that no problem occurred 
during the construction period because there was no overall plan at the initial stage of construction, which seems to correspond with the situation on site.

In Case 4, a retrofit of up to seven floors in the initial plan was completed only up to the second floor and was being discontinued. The reason was that the owner did not have sufficient cash flow.

In Case 5, significant construction delays and extensions were observed. Since there was a business opportunity, the store owner insisted on store operations during the religious festival period, and construction had to be suspended for almost two months. Answers such as "The shop owner was not notified by the building owner to close the stores, and construction work could not start" and "Construction work could start as the shop's upper floor was open" were given. With respect to the process, significant changes frequently occurred because of the owner's business priority or lack of awareness.

\section{Material procurement}

Details of the principal materials used for the main building are summarized in Table 5. Materials such as rebar and concrete cement are domestic materials. By contrast, Cases 1, 4, and 5 utilized micro-concrete and chemical products imported from overseas. This revealed that the adoption of new technologies from abroad has been occurring in Bangladesh.

In Case 1, according to the construction managers, "Ordered materials and equipment could not be reached." The causes included road blockades by strikes and political demonstrations. This problem was solved by changing the construction procedure. In other similar cases, a policy of "order earlier and stock" was observed. In Case 4, the manager was ready on the day before the one on which a demonstration or strike was expected.

\section{Decision-making}

Decisions on the construction process were the responsibility of the construction manager, and a flexible response could be seen with regard to the situation on site. In Case 5, "there is no specific timetable that determines the construction work."

Regarding the design layout, Case 5 shows that "due to the lack of communication between the technical consultant and the structural designer, there might be a change, and decision-making was not conducted smoothly." It was clarified that there were overlapping tasks between the consultant and the structural designer, and there were cases in which a clear delineation could avoid difficulties in decisionmaking.

\section{Laborer issues and education}

According to the construction manager, in Cases 1,4 , and 5, which used new material, the construction firm provided training on construction methods to their laborers. This was done at the beginning of a new project and was conducted every month. Conversely, in Case 3, there was no training program for laborers, and in Case 2, the unskilled laborers gradually learned from the skilled laborers.

Table 5. Procurement

\begin{tabular}{|c|c|c|c|c|c|c|}
\hline Material & Item & Case 1 & Case 2 & Case 3 & Case 4 & Case 5 \\
\hline \multirow[t]{2}{*}{ Concrete } & $\begin{array}{l}\text { Utilized } \\
\text { concrete, }\end{array}$ & Micro concrete & $\begin{array}{l}\text { On-site mixed } \\
\text { concrete }\end{array}$ & $\begin{array}{l}\text { On-site mixed } \\
\text { concrete }\end{array}$ & \multicolumn{2}{|c|}{$\begin{array}{l}\text { Micro concrete Micro concrete, on-site } \\
\text { mixed concrete, ready- } \\
\text { mixed concrete }\end{array}$} \\
\hline & Supplier & India & Domestic & Domestic & India & India \\
\hline \multirow[t]{2}{*}{ Aggregate } & Aggregate & Brick chip & Brick chip & N/A & Stone chip & Stone chip \\
\hline & supplier & Domestic & Domestic & Domestic & Domestic & Domestic \\
\hline \multirow[t]{5}{*}{ Iron } & Existing iron & $\Phi 27 \pm 3$ & N/A & N/A & $\Phi 16,20$ & N/A \\
\hline & Form for use & Deformed & Deformed & Deformed & Deformed & Deformed \\
\hline & $\begin{array}{l}\text { Column/beam } \\
\text { (main: hoop) }\end{array}$ & None/Ф10,16 & $\begin{array}{l}\Phi 25: \Phi 10 / \\
\Phi 12,20: \Phi 8,10\end{array}$ & N/A & $\begin{array}{l}\Phi 12,16,20 / \\
\text { None }\end{array}$ & $\Phi 16,20: \Phi 10 /$ none \\
\hline & Slab/basement & Slab: $\Phi 10$ & Basement: $\Phi 16$ & None & None & None \\
\hline & Supplier & Domestic & Domestic & Domestic & Domestic & Domestic \\
\hline Brick & Existing brick & Brick & Brick & Brick & Brick & Brick \\
\hline \multirow[t]{2}{*}{ Other } & Other & $\begin{array}{l}\text { Polyester resin } \\
\text { grout, epoxy } \\
\text { grout }\end{array}$ & - & - & $\begin{array}{l}\text { Polyester grout, } \\
\text { epoxy grout }\end{array}$ & $\begin{array}{l}\text { Polyester resin grout, epoxy } \\
\text { grout }\end{array}$ \\
\hline & Supplier & India & - & - & India & India \\
\hline
\end{tabular}


When interviewing laborers on how they learned construction techniques, they answered "In the past, he learned from his father" or "learning from experience." Therefore, the laborers identified that knowledge of new techniques is gained over several years of experience.

There was no situation in which laborers made decisions by themselves at the construction stage, so the work was advanced by extensive communication with the foreman and the construction manager. In addition, Cases 2 and 3 had to contend with issues such as "Laborer cannot read design accurately." To be more specific, "They can roughly understand the numbers and size notations on diagrams, but it is hard for them to understand material names that are written in English." Although design drawings were written in English, most of the laborers could understand only their mother tongue, i.e., Bengali. Currently, this has been solved by close communication with the construction manager. However, along with the adoption of new materials in Bangladesh, laborer education is essential to spread technology in a way that the donors of the technology intend.

\section{Technical Stakeholder Analysis}

Figure 1 illustrates the overall characteristics of the case studies. The stakeholders in Cases 1 and 5 included the owners, technical consultants, structural design engineers for the general contractor, and construction management site engineers. Note that the technical consultant was independent of the structural design engineer. In addition, the research institute participated as a consultant contracted directly by the owner. Construction contracts were secured between the owner and the general contractor.

In Case 4, Contractor $\mathrm{E}$ participated in the construction work and served as a technical consultant and site engineer. However, in Case 1, the research institute, which participated as the technical consultant in Case 5, assumed the role of the structural designer. This was a special case wherein a participant assumed a dual role. There was a contract between the owner and the structural design engineer, and the construction contract was secured between the owner and the general contractor, to which all of the laborers belonged.

For Cases 2 and 3, contracts were signed for turnkey projects in which the owner employed the general contractor and a local construction firm. In practice, the general contractor managed the local construction firm and performed the roles of technical consultant and structural designer.
From the results provided in Table 6, the documentation of existing buildings was quite deficient. Detailed information such as structural characteristics required collection through on-site surveys. Moreover, building assessments were conducted to produce design documents that were not generated at the time of construction, particularly for post-disaster repair, reconstruction, and rehabilitation. Even when a design document existed, in case there was doubt, the tests were required to be conducted.

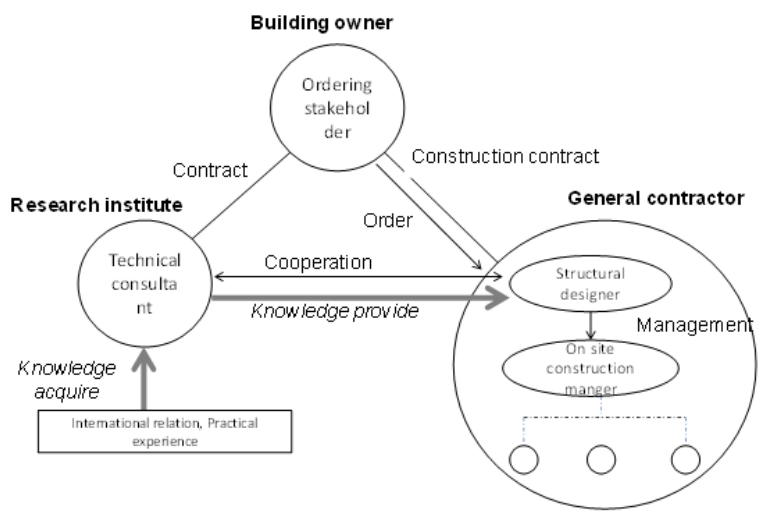

Case 1 and Case 5

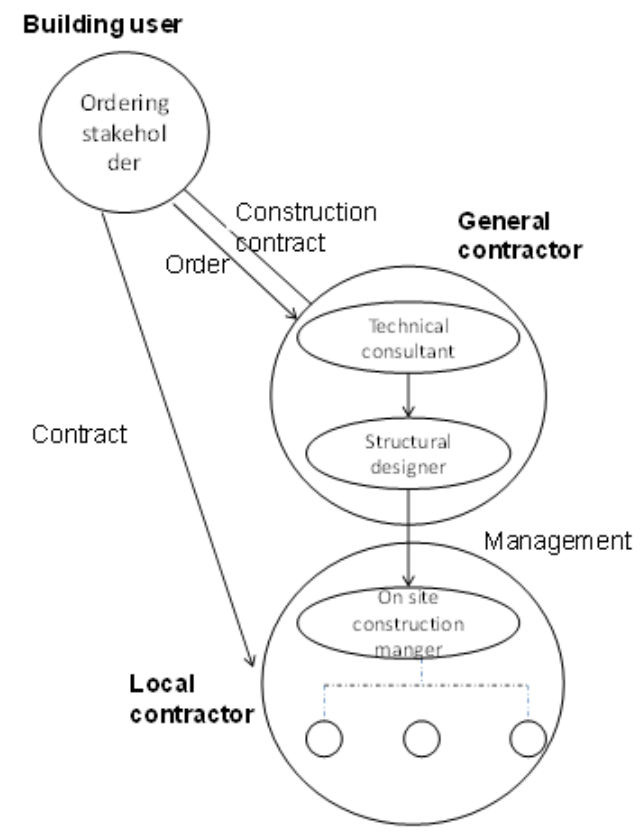

Case 2 and Case 3

Fig. 1. Contract Relationship

Figure 2 shows the technical stakeholders' roles and responsibilities in each process: "request," "assessment," "design," and "construction."

In Case 1, the owner directly orders the general contractor and proposes Research Institution B as a technical consultant. 
Table 6. Stakeholder Roles

Case Case 1

Case 2

Case 3

Case $4 \quad$ Case 5

Technical consultant Knowledge provider/Assessment/ Knowledge provider/ Design check Assessment/Design

Structural designer Design/Consulting

Construction

Period management/quality management/ procurement Knowledge provider/ Assessment/Design check manager

\begin{tabular}{|c|c|c|c|c|c|}
\hline & Owner & Consultant & $\begin{array}{c}\text { Structural } \\
\text { desinger }\end{array}$ & $\begin{array}{c}\text { Construction } \\
\text { manager }\end{array}$ & labor \\
\hline \multirow[b]{2}{*}{ Order } & order & & & & \\
\hline & decide & & $\begin{array}{c}\text { suggest } \\
\text { consultant }\end{array}$ & & \\
\hline \multirow{3}{*}{ Asse ssment } & & dicide method & & & \\
\hline & & diagnosis & & & \\
\hline & & result & & & \\
\hline \multirow{5}{*}{ Retrofit plan } & decide & $\begin{array}{c}\text { suggest } 3 \text { retrofit } \\
\text { methods }\end{array}$ & & & \\
\hline & & $\begin{array}{l}\text { structural } \\
\text { calculation }\end{array}$ & participation & & \\
\hline & & & $\begin{array}{c}\text { structural design. } \\
\text { specification }\end{array}$ & & \\
\hline & & check & & & \\
\hline & & modification & & & \\
\hline \multirow[b]{2}{*}{ Construction } & & site visit & & & \\
\hline & & quality inspection & $\begin{array}{l}\text { quantity } \\
\text { estimation }\end{array}$ & \begin{tabular}{|c|} 
quality assurance. \\
time mana gement. \\
procurement
\end{tabular} & construction \\
\hline
\end{tabular}

Fig. 2. Construction Process. Case 1

\begin{tabular}{|c|c|c|c|c|c|}
\hline & owner & $\begin{array}{l}\text { architectural } \\
\text { desinger }\end{array}$ & $\begin{array}{c}\text { consultant } \\
\text { structural } \\
\text { desiener }\end{array}$ & $\begin{array}{l}\text { construction } \\
\text { manager }\end{array}$ & labor \\
\hline order & order & & & & \\
\hline assessment & & & $\begin{array}{c}\text { decide diagnosis } \\
\text { method }\end{array}$ & & \\
\hline & & & result & & \\
\hline \multirow{5}{*}{ retrofit plan } & opinion & $\begin{array}{c}\text { architectural } \\
\text { desien }\end{array}$ & & & \\
\hline & & & $\begin{array}{c}\text { suegest } 1 \text { retrofit } \\
\text { method }\end{array}$ & & \\
\hline & & & decide & & \\
\hline & & & $\begin{array}{l}\text { structural } \\
\text { calculation }\end{array}$ & & \\
\hline & decide & & $\begin{array}{l}\text { structual design, } \\
\text { specification }\end{array}$ & & \\
\hline \multirow[b]{2}{*}{ construction } & & & site visit & & \\
\hline & & & $\begin{array}{c}\text { quantity } \\
\text { estimation, quality } \\
\text { inspection }\end{array}$ & $\begin{array}{c}\text { equality } \\
\text { mana gement, time } \\
\text { management. } \\
\text { procurement }\end{array}$ & construction \\
\hline
\end{tabular}

Fig. 3. Construction Process. Case 2 


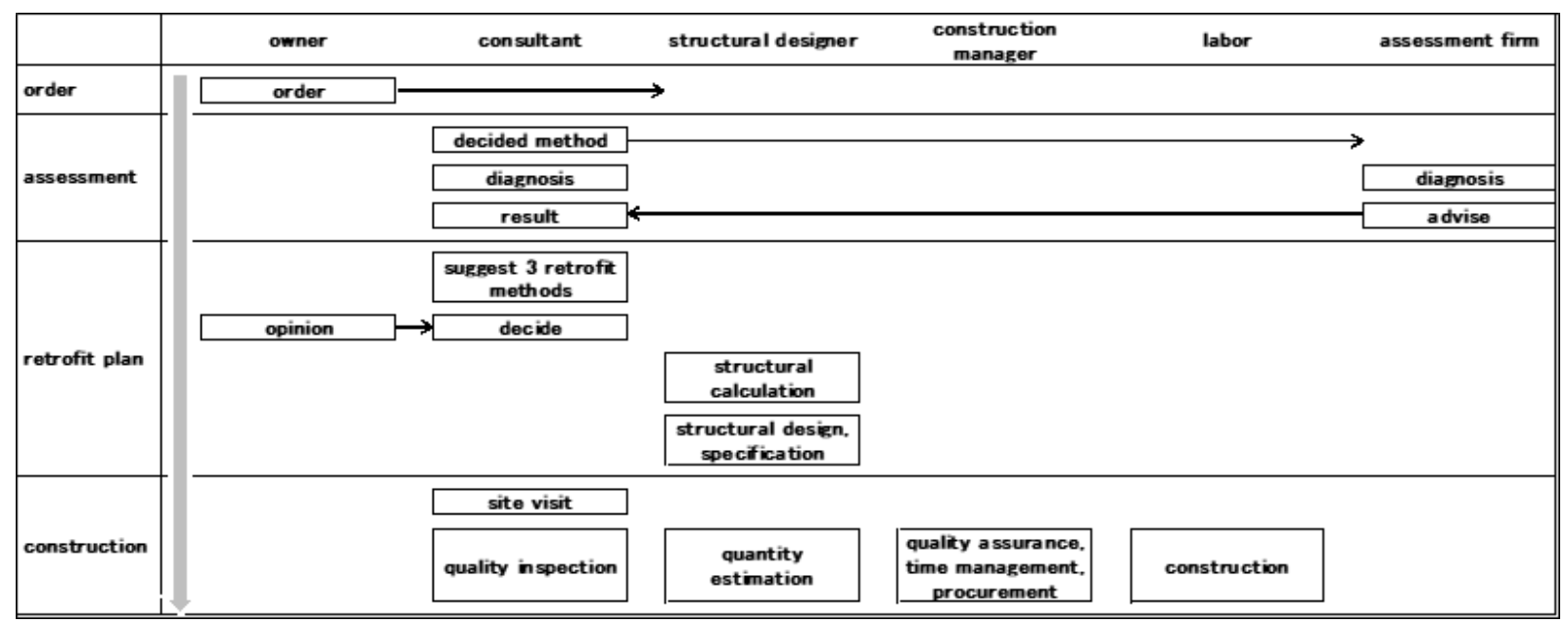

Fig. 4. Construction process. Case 4

Various methods of assessment and retrofit construction are proposed by the technical consultant, and the owner makes a final decision. After structural calculations by the consultant, the structural designer prepares drawings and specifications. Once the construction is completed under the site engineer, the consultant conducts inspection and supervision.

In Cases 2 and 3, the owner requests the stakeholder, who performs the dual role of technical consultant and structural designer. They also perform diverse roles such as decision-making for the assessment and construction methods, conducting the assessment, and preparing structural drawings and specifications. Moreover, they perform quality control, process management, and procurement at the construction stage. At the time of selecting the construction method, the owner also participates in the decision-making.

Case 4 is a case in which Contractor $\mathrm{E}$ is involved. The determination of the assessment method is conducted by the consultants and a specific diagnostic firm participates as an adviser. Consultants also perform their own assessment. Structural calculations, design drawing preparation, and specification preparation are performed by a structural designer. During construction, the consultant for inspection and supervision is the same as in Case 1.

In Case 5, the assessment and construction methods are proposed and determined by the technical consultant. However, selecting the construction method is also performed by the owner. After the structural calculations by the technical consultants, the structural designer prepares the design and specifications. During the project, construction is conducted by the contractor and the consultant inspects and supervises.
The role of each technology in a structural retrofit in Bangladesh is not clearly delineated through an overview of each process. It was confirmed there are several cases in which roles overlap between the stakeholders and that the same engineer could have multiple roles. For example, one interviewee, a site engineer who belonged to a firm in the private sector, established a private consulting firm and mentioned, "It is inevitable in order to survive in the construction industry of Bangladesh."

The main role of each technology is summarized in Table 6 from the process diagrams of the five cases. Technical consultants provide technical knowledge, structural designers are responsible for the structural design, and construction engineers have the role of inspecting process control, quality management, and procurement.

The case of Contractor $\mathrm{E}$ has various technical stakeholders, and the roles have been divided among the technical consultant, structural designer, and building diagnostics company. As the technical consultants and the structural designers are different stakeholders, technology consultants have roles such as checking the actual work after advising on the structural design in each process. The case in which the structural designer participates in consulting is also observed. In addition, the person participating as a structural designer from Contractor $\mathrm{E}$ is also responsible for consulting on the subsequent construction in Case 4, in which the research institution has joined as a structural designer. Through cases in which research institutions are involved, private companies have begun to introduce knowledge sharing in practice. Cooperation with academia has been shown to create technical trial opportunities for private companies. 


\section{DISCUSSION}

\section{Spontaneous Technology Transfer}

In Cases 1, 4, and 5, the phenomenon of technology transfer from overseas can be observed. When a general contractor partnered with an international materials manufacturer for the use of imported material, an advocated design and construction policy was introduced. The techniques used in each case were based on the knowledge and experience of technical consultants. In Cases 1, 4, and 5, academicians conducted building diagnostics with precise inspection and proposed new imported building materials, such as iron plates and fiber sheets. Conversely, in Cases 2 and 3, indigenous technology was used on the basis of practical experience. The difference is that technical stakeholders specified the level of technology such as diagnostic techniques, materials, and the variation and level of the proposed construction method.

In cases where new technology was used, technical knowledge that was based on academicians' experience and knowledge was provided. Generally, these academicians have higher degrees from overseas universities and maintain continuous relations with the universities from which they graduated. Thus, it can be said that the academic institutes in Bangladesh play a significant role in technology transfer.

It can be seen that there is a greater choice at the time of selecting the construction method. Technical consultants are proponents of new technology and have determined the technical level of construction work. For the spread of technology in Bangladesh, the role of the technology consultant is expected to be essential.

\section{Prospective Role for Diffusion}

Cases 1, 4, and 5, in which Contractor E and Research Institute B were involved, provided oppor- tunities for technology recognition and trials for private companies. This highlights the significance of the consultant's role even when the transferred seismological technology could be diffused from Japan in the near future.

By contrast, Cases 2 and 3 used local technology that had already been used in Bangladesh. However, such local contractors are a majority in developing countries and do not voluntarily adopt new technology, continuing to use familiar technology. Thus, ways to contract without such attitudes and to create an environment for promoting new technology and inducing its adoption need to be seriously considered.

\section{Decision Factor for Adoption}

Table 7 provides a summary of decision-making related to technology adoption. At the assessment and planning stage, the selection is conducted in terms of methods, referenced standards, materials, and design policies.

By focusing on the assessment stage, attaining a sufficient technical level by adopting international standards and international manufacturers' policies is regarded as a promoting factor. The absence of equipment has become an inhibiting factor in the adoption of technology.

Regarding the method of construction, the feasibility, economy, and safety of construction are factors determining promotion or suppression, as they are in developed countries. As new materials are imported from abroad, procurement is also said to be a suppressing factor in the adoption of technology. Furthermore, in Bangladesh, when compared with developed countries, budgets are overwhelmingly low and economic factors such as cost are significant.

At the construction stages such as process management, procurement, and laborer education, factors related to the adoption of technology are not considered.

Table 7. Decision-Making Factors in Each Process

\begin{tabular}{|c|c|c|c|}
\hline Process & Decision maker & Decision matter & Decision factor \\
\hline Order & Building owner/building user & Conduction/contract firm & External factor/internal factor/legislation \\
\hline \multirow[t]{2}{*}{ Assess } & Technical consultant/ diagnostic & Method & Economic performance/equipment \\
\hline & firm/structural designer & Standard & $\begin{array}{l}\text { Manufacturer policy/international code/national } \\
\text { code }\end{array}$ \\
\hline \multirow[t]{2}{*}{ Design } & Building owner & Conduction & Engineering experience \\
\hline & Structural designer & $\begin{array}{l}\text { Method/material/ } \\
\text { design policy }\end{array}$ & $\begin{array}{l}\text { Construction } \\
\text { workability/period/procurement/economic } \\
\text { performance/efficiency/owner's indication/ } \\
\text { owner's approvability/manufacturers' policy }\end{array}$ \\
\hline Construct & Building owner/building user & Period change & Economic performance \\
\hline
\end{tabular}




\section{CONCLUSION}

In the overall retrofit process, decision-making for assessment, standards, design policies, construction methods, and materials is mainly conducted at the planning stage. In technology selection, international standards make it easy to obtain the owner's approval. This is a promoting factor in the adoption of technology. By contrast, cost and material procurement are suppressing factors. Nevertheless, the owner and the user are involved in the decision-making process. Even though the construction period is also determined by these factors, the influence of the owner on decision-making generally prevails.

It has also been clarified that academic institutions and private companies have transferred and diffused structural strengthening technology. International standards and relationships with overseas manufacturers are positive factors for the diffusion of technology. However, materials that are not produced in the country are negative factors from the perspectives of the economy and procurement.

The stakeholders for providing and spreading new technology are technical consultants and structural designers, who are involved in the initial phase of the frontend project. Conversely, contractors and laborers are not involved in deciding on the adoption of new technology. In order to promote the diffusion of technology in Bangladesh, acknowledging these stakeholders and considering worker education is required, and investigation in these areas is expected in the future.

\section{ACKNOWLEDGMENT}

This research was supported by the Fuji Xerox Kobayashi fund. All of the kind support for the case study is gratefully acknowledged.

\section{REFERENCES}

Akihiko, T., Syochi, A., \& Kenji, O. (2013). Comparative study on non-engineered construction in developing countries. Tokyo: Architectural Institute of Japan, 78, 907-914.

Akihiko, T. (2013). Study on constraints to improve the earthquake resistance of non-engineered houses with factor analysis methods. Doctoral thesis. Kanagawa: Yokohama National University.

Rumiko, S., Tsuyoshi, S., \& Yongsun, K. (2014). Decision-making process and stakeholder's role of retrofit in Bangladesh. Kinki: Architectural Institute of Japanese annual conference. (In Japanese).
Hideaki, K., \& Satoru, S. (2001). A study on determining development factors and their components for technical cooperation to developing countries in architectural area. Tokyo: Architectural Institute of Japan, 550, 225-233.

Hideaki, K. (2003). A study on development factors for disaster prevention area in developing countries. Tokyo: Summaries of technical papers of Annual Meeting, Architectural Institute of Japan, 441-442.

Hideaki, K. (2004). Analysis and evaluation on social factors in technical cooperation of disaster prevention area. Tokyo: Summaries of technical papers of Annual Meeting, Architectural Institute of Japan, 385-386.

Hideaki, K. (2006). A study on access, vulnerability and recovery from earthquakes in developing countries. Tokyo: Summaries of technical papers of Annual Meeting, Architectural Institute of Japan, 503-504.

Shuzo, F., Osamu, F., \& Kazuyoshi, E. (1988). Technology transfer of building construction to developing countries. Tokyo: Summaries of technical papers of Annual Meeting, Architectural Institute of Japan, 611-612.

Shuzo, F., Osamu, F., \& Kazuyoshi, E. (1989). Technology transfer of building construction to developing countries (2). Tokyo: Summaries of technical papers of Annual Meeting, Architectural Institute of Japan, 537-538.

Kenji, O. (2003). Research on motivation and management of sustainable earthquake disaster prevention in developing countries- Through implementation of the United Nations RADIUS (urban disaster countermeasure promotion) project -. Doctoral thesis. Kyoto: Kyoto University.

Chankong, V., \& Haimes, Y. Y. (1983). Multiobjective decision-making -Theory and Methodology. North-Holland, New York

Lesniak. A., \& Plebankiewicz. E. (2013). Modeling the decision-making process concering participation in construction bidding. Journal of Management in Engineering, ISSN (online) 19435479.

Chua, D. K. H., Li, D. Z., \& Chan, W. T., (2001). Case-Based Reasoning Approach in Bid Decision Making. Technical Paper, Journal of Construction Engineering and Management, 127(1).

Ling, F., \& Bui, T., (2010). Factors affecting construction project outcomes: Case study of Vietnam: ASCE Case studies: EI.1943-5541. 0000013, 148-155

Nguyen, L., Phan, D., \& Tang, L, (2013). Predicting Construction Duration with Typical Construction Sequences for High-Rise Buildings. Architectural Engineering Conference, ISBN (print): 978-0-7844-1290-9. 
Tam, C.M., Deng, Z.M., \& Zeng, S.X. (2002). Evaluation of construction methods and performance for high rise public housing construction in Hong Kong. Building and Environment, 37, 983-991.

Hurtado, B., \& Bruno, G. (2005). El Proceso de Analisis Jerarquico (AHP) como Herramienta para la toma de decisions en la selection de proveedores. Universidad Nacional Mayor de San Marcos, Peru.

Ling, Y.Y. (2003). A conceptual model for selection of architects by project managers in Singapore. International Journal of Project Management, 21(2), 135-144.

Ng, S. T., \& Chow, L. (2004). Evaluating engineering consultants' general capabilities during the preselection process- A Hong Kong Study. Construction. Archit. Management, 11(3), 150-158.

Ximena, F., \& Alfredo, S. (2014). Selection of construction Methods for Construction Projects: A Knowledge Problem. Journal of Construction Engineering and Management, 140(4), B4014002.

Youssef, M., Anumba, C., \& Thorpe, T. (2005). Intelligent selection of concrete bridge construction methods in Egypt. Proceeding 2005 ASCE International Conference on Computing in Civil Engineering, ASCE, Reston. VA.

Soetanto, R., Glass, J., Dainty, A., \& Price, D. (2007). Structural frame selection: Case studies of hybrid concrete frames. Building Res. Inf., 35(2), 206-219.

Castro-Lacouture, D., Sefair, J. A., Florez, L., \& Medaglia, A. L. (2009). Optimization model for the selection of materials using a LEED-based green building rating system in Colombia. Building Environment, 44(6), 1162-1170.

Yun, Z., Florence, Y. Ling., \& Peng. Wu. (2017). Journal of Construction Engineering and Management, CO.1943-7862.0001210.
Kanter, J. (1999). Knowledge management: Practically speaking. Infl. Syst. Management, 16(4), 715.

Ahmed, M. G., John, M. K., Chimay, J. \& Anumba. (2006). Prototype System for Knowledge Problem Definition. Journal of Construction engineering and Management, 132(5), 516-524.

Nonaka, I., \& Takeuchi, H. (1995). The knowledge creating company: How Japanese companies create the dynamics of innovation. Oxford University Press, New York.

Vail, E. F., (1991). Knowledge mapping: Getting started with knowledge management. Inf. Syst. Management, 16(4), 16-23.

Yi, Z., Yang, Miang., Brian H.W., \& Guo (2016). Journal of Construction Engineering and Management, CO.1943-7862.0001279.

Gibson. G. E., \& Hamilton, M. H. (1994). Analysis of pre-project planning effort and success variables for capital facility projects. Rep. SD-105, Construction Industry Institute, Univ. of Texas at Austin, Austin, TX.

Bon-Gang, H., \& Jia, W.H., (2012). Journal of Construction Engineering and Management, 138(4): 567-573.

Simon, H.A. (1945). Theory of Games and Economic Behavior. John Von Neumann, Oskar Morgenstern: American Journal of Sociology, 50(6), 558.

March, J.G., Simon, H.A. (1958). Organizations. : Willey Organizations. Oxford, England.

Charles E. Lindblom. (1959). The Science of "Muddling Through". Public Administration Review, 19(2), 79-88.

Mintzberg, H., Raisinghani, D., \& Theoret, A. (1976). The structure of "Unstructured Decision Processes. Administrative Science Quarterly, 21(2), 246-275.

Michael D.C., James G.M., \& Johan P.O. (1972). A Garbage Can Model of Organizational Choice. Administrative Science Quarterly, 17(1), 1-25. 